\title{
Cervantes y don Quijote en el universo poético lezamiano
}

\author{
Macarena Cuiñas GómeZ*
}

Nadie duda a estas alturas que la literatura española del barroco ha sido tan importante para nuestras letras posteriores como para la desarrollada al otro lado del océano. Compartimos con América lengua y cultura, enriquecidas, allá, por la mezcla habida con los grupos humanos, muchas veces indígenas, de los pueblos tan distintos que conforman el centro y sur del continente americano. El escritor cubano José Lezama Lima (1910-1976) es buen ejemplo de ello. Admirador confeso de Don Luis de Góngora, muestra una escritura las más de las veces oscura y compleja, llena de variedad y riqueza, suma de su gran cultura y su dominio del lenguaje, fruto de sus voraces lecturas, muchas de ellas de corte clásico. Y desde luego no podía faltar en su bagaje cultural una buena lectura del Quijote que plasma en diferentes aspectos de su obra de ficción y ensayística. A esta cuestión vamos a atender en el presente artículo que pretende adentrarse en el inmenso mundo poético filosófico literario del cubano José Lezama Lima a través de su gran obra narrativa Paradiso y ciertos pensamientos al respecto de Cervantes y su inmortal personaje que plasmó en varios de sus complejos ensayos y escritos.

La primera reflexión importante de Lezama acerca del Quijote que quiero analizar se encuentra en el capítulo IX de su novela Paradiso, cuya continuación inacabada se titula Oppiano Licario. Para poder comprender el alcance de sus palabras es necesario contextualizarlas en la narración. La novela se centra en una familia cubana y, en concreto, en un niño, José Cemí, al que conocemos ya desde el inicio como un niño enfermo de asma, muy querido, muy protegido también, que ha de pasar por el duro trance de perder a su padre. Los capítulos anteriores al que nos interesa, los ocho primeros,

* Universidad de Vigo. 
transcurren a lo largo de su infancia, el citado óbito familiar, la experiencia escolar, la importancia de la familia y la sexualidad, no como iniciación sino como experiencia a la que despierta en un sentido de conocimiento. $\mathrm{Y}$ es entonces cuando llegan sus años universitarios. Comienza el capítulo IX con su primer día en Upsalón acompañado de una revuelta estudiantil, una manifestación magistralmente descrita por Lezama llena de color y movimiento que transcurre a lo largo de varias calles de la Habana. Esta revuelta propicia el encuentro fugaz con Ricardo Fronesis, el que será su gran amigo, y con Eugenio Foción, que completará el triángulo de amistad. Una vez de vuelta a casa mantiene con su madre una conversación sobre el padre muerto y, después, le sobreviene un ataque de asma que le postra durante unas horas de descanso. Tras ese tiempo decide pasear por las calles habaneras y reflexiona acerca de sus lecturas. De nuevo vuelve a Upsalón, a la escuela de Filosofía y Letras, donde asiste a clases y a su salida mantiene una inteligente conversación con Fronesis acerca, entre otras cuestiones, del Quijote. Y esta es la parte que más nos interesa para este estudio. Recordemos que en este capítulo se narra para el protagonista, José Cemí, la llegada a la universidad, al conocimiento, se produce el encuentro con el otro, el diálogo, la amistad, la tríada formada por Cemí-Fronesis-Foción, tan importante en sus vidas. Se produce, por lo tanto, la salida del mundo familiar, protector, y la llegada al mundo del conocimiento a través de los libros, $\mathrm{y}$, sobre todo, a través de la interacción con el otro con el que comparte intelectualidad y afecto.

Raquel Carrió Mendía destaca que "La ubicación de la manifestación estudiantil en el primer día de clases y en el comienzo del capítulo constituye un signo preciso: sitúa el relato en un contexto histórico, político, cuyo valor no se reduce a un episodio del texto; establece un sustrato en la caracterización de la década." (p. 663) ${ }^{1}$. Se trata de la rebeldía, la inquietud protestataria, la afirmación del yo y de un modo personal de vida. Aunque esta cuestión perteneciente a este capítulo es un pequeño elemento que conforma el inmenso universo poético de Paradiso, sembrado aquí y allá de referencias culturales, reflexiones filosóficas, literarias, religiosas, impregnado del ser cubano y de la cultura y la intelectualidad con mayúsculas, y en el que cabe también la expresión del sentimiento y el afecto, sobre todo familiar y de amistad. Resulta muy difícil resumir el contenido y significado de la novela lezamiana sin tener que obviar una gran parte de su riqueza que el lector apreciará en toda su extensión.

Pero vayamos con el análisis del pasaje que nos interesa. Es un narrador el que inicia el comentario acerca del Quijote, después de realizar una fuerte crítica hacia las clases universitarias, vacías de contenido, carentes de interés. Parece que el alumno solamente podía enriquecer su intelecto en las charlas de pasillo. El profesorado muestra el estudio del Quijote como una novela que

1. Raquel Carrió Mendía, "Capítulo IX. Paisaje, historia y cultura”, en Paradiso, ed. crítica de Cintio Vitier, Nanterre: Archivos, 1988, pp. 662-667.

ANALES CERVANTINOS, VOL. XXXVII, PP. 297-311, 2005. ISSN: 0569-9878 
parte de un planteamiento de romance carolingio, exponiendo una lectura unívoca del texto, una lectura finista: la gran novela cervantina es el fin de la filosofía escolástica, de la literatura de caballerías medieval. Esta idea era expresada en 1905 por Marcelino Menéndez Pelayo, filólogo muy criticado por Lezama como veremos más adelante, que dice textualmente: "Fue de este modo, el Quijote, el último de los libros de caballerías, el definitivo y perfecto, [...]" (p. 21) $)^{2}$. A esto era reducido sin tener en cuenta: "[...] lo que hay de acto participante en el mundo del Oriente, de un espíritu acumulativo instalado en un ambiente romano durante años de su juventud, que con todas las seguridades del Mediterráneo Adriático, se abre a los fabularios orientales." $(P, 391)^{3}$. Esto es, sin tener en cuenta la fabulación, la imaginación, que Lezama identifica más con el mundo oriental que con el occidental, como cultura más rica en imágenes. Lo que sitúa al Quijote, y a Cervantes como su creador, en un nivel de apertura mental hacia un mundo imaginativo, cargado de simbolismo, camino por el que alcanza la elaboración de un texto moderno y diferente.

Pero Don Quijote sale del aula para continuar sus andanzas entre los estudiantes universitarios que conversan por los pasillos. Es Ricardo Fronesis el que lleva la voz cantante y comienza por criticar al profesorado que afirma que el Quijote se inicia de esa manera porque Cervantes se halla en una prisión:

"Me parece insensato opinar como el vulgacho profesoral, que Cervantes comienza el Quijote con las conocidas frases que lo hace por haber estado preso, no debía el Quijote comenzar como lo hace, y no por ocultar su prisión, ya Cervantes había llegado a un momento de su vida en que le importaba una higa el denuesto o el elogio, pues como él dice: "me llegan de todas partes avisos de que me apresure"." (P, 391).

De hecho el propio Cervantes reconoce sin ningún pudor que ha estado en la cárcel en su Prólogo al Quijote:

"Desocupado lector: sin juramento me podrás creer que quisiera que este libro, como hijo del entendimiento, fuera el más hermoso, el más gallardo y más discreto que pudiera imaginarse. Pero no he podido yo contravenir al orden de naturaleza, que en ella cada cosa engendra su semejante. Y, así, ¿qué podía engendrar el estéril y mal cultivado ingenio mío, sino la historia de un hijo seco, avellanado, antojadizo y lleno de pensamientos varios y nunca imaginados de otro alguno, bien como quien se engendró en

2. Marcelino MenÉndez Pelayo, "Cultura literaria de Miguel de Cervantes", en Cervantes. Cultura literaria. 450 Aniversario del nacimiento de Cervantes, Alcalá de Henares: Centro de Estudios cervantinos, 1997, pp. 7-25

3. Las citas de Paradiso referidas como $P$ remiten a la edición de Eloísa Lezama Lima, Madrid: Cátedra, 1993.

ANALES CERVANTINOS, VOL. XXXVII, PP. 297-311, 2005. ISSN: 0569-9878 
300 - MACARENA CUIÑAS GÓMEZ

una cárcel, donde toda incomodidad tiene su asiento y donde todo triste ruido hace su habitación?"4.

Fronesis no niega que Cervantes comenzase a escribir el Quijote en una cárcel, pero sí que las primeras palabras del mismo se refieran a esta circunstancia, y más abajo conocemos el porqué cuando habla del Guzmán de Alfarache:

"Desde sus comienzos se alude en esa obra a un ambiente de prisión "escribe su vida desde las galeras, donde queda forzado al remo". Razón de más para que Cervantes no comenzase con la misma alusión.” (P, 391-392).

Efectivamente esta frase está recogida en la "Declaración para el entendimiento deste libro" impresa en los preliminares del Guzmán. Por lo tanto, Fronesis no admite que las conocidísimas frases iniciales del Quijote se refieran a su redacción en prisión porque lo igualan a la novela picaresca de Mateo Alemán, le restan originalidad y encasillan, de alguna manera, a la novela cervantina en un género. De todos modos este tema ha sido debatido ampliamente por el cervantismo y ha desembocado en dos vertientes: los que opinan que la cárcel era real y los que opinan que era citada en un sentido moral. La primera idea es desarrollada, entre otros, por Rodríguez Marín 5 y Orozco Díaz ${ }^{6}$ que apuntan a la cárcel Real de Sevilla donde Cervantes estuvo preso, dato que se corrobora con el conocimiento de una carta escrita por Cervantes desde allá7. Y la segunda idea fue propuesta por Díaz de Benjumea ${ }^{8}$, puesta al día por Américo Castro ${ }^{9}$ y rebatida por Stagg $^{10}$ que propone la cárcel de Castro del Río como lugar de inicio de la escritura del Quijote. El asunto de la prisión real de Cervantes es el que parece imponerse en los estudios actuales, siendo idea repetida por los recreadores posteriores de la obra cervantina ${ }^{11}$. Volviendo al texto

4. Edición de Francisco Rico, Barcelona: Crítica, 1998, p. 9.

5. En su edición Miguel de Cervantes, El ingenioso hidalgo Don Quijote de la Mancha, Madrid: Atlas, 1947-1949, 10 vols. y en Estudios cervantinos, Madrid: Atlas, 1947.

6. Cervantes y la novela del Barroco, ed. José LARA GARRIDO, Universidad de Granada, 1992

7. Acerca de este asunto vid. los artículos del profesor José MONTERO REGUERA "Epistolario de Miguel de Cervantes", Castilla. Estudios de Literatura, XVII (1992), pp. 81-101 y "El cervantismo del curso 1992-1993", Edad de Oro, XIII (1994), pp. 203-209.

8. La estafeta de Urganda o aviso de Cid Asam-Ouzad Benenjeli sobre el desencanto del "Quijote", Imp. de J. Wertheimer y $\mathrm{C}^{\mathrm{a}}$, Londres, 1861.

9. En sus libros y artículo Hacia Cervantes, Madrid: Taurus, 1957, De la Edad conflictiva, Madrid: Taurus, 1961, Cervantes y los casticismos españoles, Madrid-Barcelona: Alfaguara, 1966, y "El Quijote, taller de existencialidad”, Revista de Occidente, LII (1967), pp. 1-13.

10. “Castro del Río, ¿cuna del Quijote?”, Clavileño, VI (1955), pp. 1-11.

11. Véanse varios ejemplos en el libro de Santiago A. LÓPEZ NAVIA, Inspiración y pretexto. Estudios sobre las recreaciones del Quijote, Madrid: Vervuert, 2005, pp. 208, 249-253. 
lezamiano, Fronesis escoge una frase de Cervantes, "me llegan de todas partes avisos de que me apresure", que no he llegado a localizar y que parece confundir con otra, en cuanto al significado de cercanía de la muerte, que forma parte de una copla antigua incluida en la dedicatoria de Los trabajos de Persiles y Sigismunda: "Puesto ya el pie en el estribo". De todos modos, Fronesis pretende destacar la personalidad de Cervantes, forjada a lo largo de una vida azarosa que le situaba por encima de críticas o de puntualizaciones carentes de interés. Es este aspecto de su carácter el que Fronesis más admira, quizás porque se asemeja a lo que él siente en su adolescencia.

Para Fronesis, Don Quijote es como Simbad el Marino, personaje de Las mil y una noches (noches 317-335), pero sin el ave rok o ave roj, pájaro fabuloso de gran tamaño que transporta a este y que da de comer elefantes a sus crías. Esta carencia hace del ser maravilloso un ser grotesco que se cree rodeado de grandes aventuras pero al que solamente acompañan un aldeano y un burro. Con palabras textuales:

"El ave rok levita a Simbad y lo lleva a l'autre monde, pero Sancho y su rucio gravitan sobre Don Quijote y lo siguen en sus magulladuras, pruebas de su caída icárica.” (P, 391).

Fronesis continúa volviendo sobre la circunstancia en la que se inició la escritura del Quijote: en una cárcel. Narra cómo Cervantes se encontró allí con Mateo Alemán que ya tenía escrita la primera parte de su Guzmán de Alfarache y estaba escribiendo su San Antonio de Padua (1604). A este respecto Márquez Villanueva afirma que "No se han confirmado las objeciones de Astrana Marín contra la probabilidad de que Alemán y Cervantes compartieran las incomodidades y tristes ruidos de la cárcel real de Sevilla en 1602"12. Quizás Lezama, en esta ocasión, haga un guiño a la crítica cervantina, con Américo Castro a la cabeza ${ }^{13}$, que mantiene que el Quijote es una respuesta a la primera mitad del Guzmán de Alfarache de Alemán ${ }^{14}$. Lo que sí está claro es que remite a la interesante relación personal, literaria, de crítica mutua, que mantuvieron estos dos grandes de la literatura del momento ${ }^{15}$.

12. Francisco MÁrquez Villanueva, Trabajos y días cervantinos, Alcalá de Henares: Centro de Estudios cervantinos, 1995, pp. 242-243.

13. Américo CASTRo, Cervantes y los casticismos españoles, Madrid: Alianza, Alfaguara, 1974, pp. 62-68.

14. Márquez Villanueva, en el texto antes citado, nota 8 páginas 244-245, se refiere a esta cuestión aportando bibliografía al respecto de cervantistas como Américo Castro, Edward C. Riley, Ricapito, Alban K. Forcione, Juan Carlos Ghiano o Daniel P. Testa. También cabría añadir trabajos de Francisco Rico y José María Micó, ambos editores del Guzmán.

15. En este sentido se desarrolla el artículo de Marcel BATAILLON titulado "Relaciones literarias", Suma cervantina, editada por J. B. AvAlLE-ARCE y E. C. RILEY, London: Tamesis Books Limited, 1973, pp. 215-232. 
Fronesis se centra en la narración somera de la desgraciada vida de este autor y compara los personajes de Don Quijote y San Antonio:

"Mientras Cervantes va escribiendo el Quijote, a su lado Mateo Alemán está escribiendo la vida de un santo, Antonio de Padua, que lucha contra el dragón, multiplicado en innumerables espejos diabólicos para su tentación." (P, 392).

Además aprovecha para rebatir otra idea suministrada por el profesor en el aula:

"Si Cervantes hubiese querido escribir contra los libros de caballería, y esa es una de las tonterías que le hemos oído al profesor esta mañana, hubiese escrito una novela picaresca, pero no, lo que hace es un San Antonio de Padua grotesco, que ni siquiera conoce los bultos que lo tien$\tan . "(P, 392)$.

Esta teoría repetida por los críticos cervantinos ${ }^{16}$ se basa en palabras del propio Cervantes en su Quijote que explicita su intención de acabar con los libros de caballería. Dice en el prólogo:

"[...] este vuestro libro no tiene necesidad de ninguna cosa de aquellas que vos decís que le falta, porque todo él es una invectiva contra los libros de caballerías, de quien nunca se acordó Aristóteles, ni dijo nada San Basilio, ni alcanzó Cicerón, ni caen debajo de la cuenta de sus fabulosos disparates las puntualidades de la verdad, ni las observaciones de la astrología, ni le son de importancia las medidas geométricas, ni la confutación de los argumentos de quien se sirve la retórica, ni tiene para qué predicar a ninguno, mezclando lo humano con lo divino, que es un género de mezcla de quien no se ha de vestir ningún cristiano entendimiento." (p. 17) ${ }^{17}$.

Y en las últimas frases de la novela:

"[...] pues no ha sido otro mi deseo que poner en aborrecimiento de los hombres las fingidas y disparatadas historias de los libros de caballerías, que por las de mi verdadero don Quijote van ya tropezando y han de caer del todo sin duda alguna." (p. 1223) ${ }^{18}$.

16. Véase por ejemplo, Martín de RIQUER, "Cervantes y la caballeresca", Suma cervantina, editada por J. B. Avalle-Arce y E. C. Riley, London: Tamesis Books Limited, 1973, pp. 273-292.

17. Miguel de Cervantes, Don Quijote de la Mancha, edición del Instituto Cervantes dirigida por Francisco Rico, Barcelona: Crítica, 1998.

18. Op. cit. nota 17.

ANALES CERVANTINOS, VOL. XXXVII, PP. 297-311, 2005. ISSN: 0569-9878 
Por lo tanto, Cervantes escribe contra los libros de caballerías, y para ello bebe de sus fuentes y las parodia dando paso del romance medieval a la novela moderna.

Y finalmente reincide en la comparación entre el personaje cervantino y el santo de Padua y el marino Simbad:

"Esa mezcla de Simbad sin circunstancia mágica y de San Antonio de Padua sin tentaciones, desenvolviéndose en el desierto castellano, donde la hagiografía falta de circunstancia concupiscible para pecar y de la lloviznita de la gracia para mojar los sentidos, se hace un esqueleto, una lanza a caballo." (P, 392).

Para Fronesis Don Quijote es comparable a dos personajes, uno fantástico y el otro real, envueltos en la magia de lo maravilloso que ocurre a su alrededor. Pero a nuestro hidalgo manchego no le asiste el entorno, solamente él lo percibe magnífico y aventurero, lo que le vuelve grotesco a los ojos de los demás hombres.

Entonces interviene José Cemí para criticar a la crítica cervantina española comenzando por Menéndez Pelayo y el seminario alemán de filología:

"La crítica ha sido muy burda en nuestro idioma. Al espíritu especioso de Menéndez Pelayo, brocha gorda que desconoció siempre el barroco, que es lo que interesa de España y de España en América, es para él un tema ordalía, una prueba de arsénico y de frecuente descaro. De ahí hemos pasado a la influencia del seminario alemán de filología. Cogen desprevenido a uno de nuestros clásicos y estudian en él las cláusulas trimembres acentuadas en la segunda sílaba." (P, 392).

Lezama Lima dedica un ensayo a la crítica de las teorías de Menéndez Pelayo llamado "La curiosidad barroca". El cubano es demoledor con el análisis del español, probablemente guiado por la concepción que Menéndez Pelayo tenía de la poesía de Góngora y que expresó en su Historia de las ideas estéticas. Dice así: "Góngora se había atrevido a escribir un poema entero [Las Soledades], sin asunto, sin poesía interior, sin afecto, sin ideas, una apariencia o sombra de poema, enteramente privado de alma" 19 . Menéndez Pelayo, junto a Américo Castro y otros, formaban el Centro de estudios Históricos que pretendía el estudio científico de nuestra literatura. Esta generación se preocupa especialmente por la lírica y en concreto por Lope de Vega, Góngora y Cervantes. También hay que incluir en este período la filosofía orteguiana de la Deshumanización del arte que Dámaso Alonso interpreta y aplica al estudio de

19. Este fragmento se encuentra en el tomo I, p. 807, pero yo lo cito por José PoRToLÉs, Medio siglo de Filología española (1896-1952). Positivismo e idealismo, Madrid: Cátedra, 1986, p. 141. 
la literatura. De este modo queda abonado el camino para la llegada de la estilística italiana y alemana con Croce y Vossler a la cabeza. Esta última vertiente es la que Lezama llama "seminario alemán de filología".

Pero sobre todo critica la falta de profundidad en el estudio de los clásicos españoles como un Thibaudet lo hizo con Mallarmé en varios libros publicados entre 1922 y 193720 . Pone el ejemplo de la inexistencia del estudio de la relación entre Góngora y el Inca Garcilaso de la Vega, para Cemí esta relación tuvo que ser muy enriquecedora para el poeta andaluz en cuanto a la inspiración de un mundo nuevo de imágenes y metáforas. Dice el texto:

"Por ejemplo, en Góngora, es frecuente la alusión a las joyas incaicas, sin embargo, no se ha estudiado la relación de Góngora con el inca Garcilaso, en el tiempo en que ambos coincidieron en Córdoba. Los incas en la imaginación de Góngora con el Conde de Villamediana, se desconocen o se silencian, a pesar de las constantes alusiones de Quevedo, erupciones más que alusiones. La imaginación retrospectiva, tan fundamental como cuando crea mundo o simples planetas zumbantes, tiene un placer interminable, los relatos que le hacía el inca Garcilaso a Góngora de una de las eras imaginarias, la tierra despidiendo imágenes, tienen que haber sobresaltado los sentidos del racionero mayor, en el momento en que se llevaba una enorme ración para su metáfora y su venablera." (P, 392-393).

Efectivamente está comprobado que Góngora y el inca Garcilaso coincidieron en Córdoba, donde el último vivió desde 1592 hasta su muerte en 1616. De hecho Garcilaso de la Vega compró algunos censos a Don Luis ${ }^{21}$. Pero esta cuestión incaica va más allá en el sistema poético lezamiano. Una de las llamadas por él eras imaginarias es "Las piedras incaicas", denominada así por el Machu Pichu, en la que las piedras guardan el misterio de la imagen. Por lo tanto, esta referencia adquiere en Paradiso un nuevo significado: el del valor de la imagen poética-literaria barroca en palabras de Góngora, el Conde de Villamediana o Quevedo, estimuladas por la metáfora americana, también barroca, primordial para Lezama Lima, piedra sobre la que se construye su modo de entender la poesía como literatura última.

Se expresa la alegría de Ricardo Fronesis por la intervención de Cemí al ver que el nuevo amigo pertenece a su ámbito. Se siente orgulloso en cierta manera y para sentirse más cerca de él, concluye: "Cervantes y Góngora hacen

20. "Mallarmé et Rimbaud", N.R.F., 1 février 1922, pp. 199-206; "Epilogue à la poésie de Stéphane Mallarmé", N.R.F., 1 décembre 1926, pp. 553-561; La Poésie de Stéphane Mallarmé, Paris: Gallimard, 1926; "Mallarmé en Angleterre et en Allemagne", N.R.F., 1 janvier 1928, pp. 95-101; “A l'ombre des contemplations: Baudelaire et Mallarmé”, N.R.F., 1 juin 1933, pp. 865-872; “La rareté et le dehors", N.R.F., 1 août 1937, pp. 235-243.

21. Carmelo SÁEnz de SAnTA María, Garcilaso de la Vega el Inca, Madrid: Historia 16, 1987, pp. 52-53. 
una literatura". Cervantes y Góngora como los grandes clásicos hispánicos, los llamados a hacer otra literatura, otra poesía. A lo que Cemí responde: "Santa Teresa y Quevedo hacen otra". Siendo también grandes pero de otro tipo, religioso, místico, intimista, la primera, y grotesco, realista, aunque brillante, el segundo.

Suena el timbre que llama a otra clase y los alumnos se dispersan. Con este pequeño repaso a la literatura áurea española estrechan lazos de amistad e inteligencia los dos amigos. Aprovecha Lezama Lima su novela para dar su opinión muy crítica acerca de la enseñanza universitaria cubana de la literatura española, y en concreto del Quijote, en boca de Fronesis, y sobre la crítica filológica existente acerca de la poesía del barroco impartida en la Isla, en boca de Cemí, (no olvidemos que nos encontramos en 1966) que, según él, no estudia en profundidad y con sentido la gran obra cervantina.

Raquel Carrió Mendía 22 ha establecido la relación de la novela lezamiana y la cervantina: "Más que un lector "hiperculto" -a veces perdido en la hipertrofia de la palabra, sonido y grafía, sin vínculo con la experiencia real, sensible- Paradiso reclama un espectador, un oyente (para la imagen sorpresiva o los ruidos de la noche) que le hizo sentir a Lezama que mejor podía entenderlo el "campesino saludable" que el "bachillerismo internacional" intoxicado de citas y fórmulas al uso o ya cambiantes en el momento de su gesticulación. Con lo cual, por otra parte, nos recuerda al Quijote - tan cercano a Paradiso, o más, que las obras de Goethe, Joyce, o En busca del tiempo perdido - en su maravilloso discurso de los cabreros." (p. 546), o discurso de la Edad dorada, expuesto por Don Quijote a unos cabreros ignorantes en el capítulo XI de la primera parte de sus aventuras.

Pero también Lezama Lima expresa en su mundo ideológico-filosófico reflexiones acerca del Quijote y de Miguel de Cervantes como vamos a analizar a continuación, sobre todo en sus textos Analecta del reloj (1953) y Tratados en la Habana (1958).

El primer libro en cuestión desarrolla un diálogo al modo platónico entre $\mathrm{X}$ y XX en el que plantean cuestiones relativas a la tradición mitológica y literaria griega junto a la simbolista de Mallarmé. Este último movimiento ofrece nuevos significados y connotaciones a las palabras/imágenes, que en los griegos resultaba más limitado. Es la palabra la que significa, pero es el tiempo el que incide en ella. El ejemplo es Cervantes que demuestra que las palabras "se liberan, por el tiempo, de la primera extensión que los traza" ( $p$. $210)^{23}$. Este "milagro" se obra en Cervantes como en nadie: sus frases, su obra, se reactualiza. El tiempo revisita las palabras de los buenos escritores

22. "La imagen histórica en Paradiso", Lezama Lima, José, Paradiso, ed. crítica de Cintio Vitier, Nanterre: Archivos, 1988, pp. 539-555.

23. José Lezama Lima, El reino de la imagen, Caracas: Ayacucho, 1981. Todas las citas de los ensayos Analecta del reloj y Tratados en la Habana son extraídas de este texto antológico. 
como Cervantes y les otorga nuevos significados. Ya no pertenecen al escritor que las escribió sino al lector. Este fragmento se encuentra en su Diario con fecha del 8 de enero de $1941^{24}$ (pp. 48-49).

En cierta manera Cervantes ya presagia la capacidad verbal del simbolismo frente a la tradición clásica griega por causa del tiempo que incide en sus palabras y llena de sentidos diferentes en las distintas épocas y en cada lector que se acerca a su obra. De ahí su valía, su enorme capacidad y talento.

En otro fragmento de Analecta del reloj (pp. 213-214) en boca del personaje denominado $\mathrm{X}$, se tratan cuestiones de índole filosófica: la continuidad temporal y la extensión espacial con relación al yo. El yo siente una resistencia en la extensión frente al otro, lo externo. Esto es fruto de la propia vida, de los impulsos, sentimientos y voliciones del ser humano. El español es contradictorio porque cree que la penetración entre el yo y la extensión hecha sustancia está reñida con su agudeza para la resistencia. Por lo tanto, tiene reparos en penetrar la extensión. Cervantes, sin embargo, alberga la certeza de que el hombre ha de penetrar violentamente la extensión, ir hacia ella, no prolongar la oposición entre el yo y la extensión. Lezama extrae esta conclusión de una frase de la novela ejemplar cervantina titulada La Gitanilla: "no te asotiles tanto que te despuntarás", expresión que ya había sido recogida en su diario el 1 de mayo de 1940 (p. 39). La frase está pronunciada por la gitana vieja en una conversación con Preciosa y significa 'no seas tan sutil, aguda, que te volverás absurda', dice: “- Ea, niña -dijo la gitana vieja-, no hables más, que has hablado mucho, y sabes más de lo que yo te he enseñado. No te asotiles tanto, que te despuntarás; habla de aquello que tus años permiten, y no te metas en altanerías, que no hay ninguna que no amenace caída." ${ }^{25}$. Luego, Cervantes rompe con la línea pensadora de los españoles, revelándose como un español singular, más audaz y avanzado.

Y en Tratados de la Habana, "Introducción a un sistema poético" (p. 272), Lezama Lima cita una frase de Viaje del Parnaso: "Aquél que tiene de escribir la llave", referencia de Cervantes al gran poeta Góngora, admirado como gran maestro por nuestro escritor cubano. De él dice textualmente: "Estotro que sus versos encarama / sobre los mismos hombros de Calisto, / tan celebrado siempre de la fama, / es aquel agradable, aquel bienquisto, / aquel agudo, aquel sonoro y grave, / sobre cuantos poetas Febo ha visto; / aquel que tiene de escribir la llave / con gracia y agudeza en tanto estremo, / que su igual en el orbe no se sabe: / es don Luis de Góngora, a quien temo / agraviar en mis cortas alabanzas, / aunque las suba al grado más supremo."26.

24. José Lezama Lima, Diarios [1939-1949/1956-1958], México: Ediciones Era, 1994, pp. 4849. Siempre que me remita al diario de Lezama me referiré a esta edición.

25. Miguel de Cervantes, Ocho novelas ejemplares, edición de José Montero Reguera, Barcelona: De Bolsillo, 2002, p. 75.

26. Capítulo II, p. 1191 de Miguel de Cervantes, Obras completas, ed. de Florencio Sevilla, Madrid: Castalia, 1999 
En "La dignidad de la poesía" (pp. 306-307), también de Tratados en la Habana, Lezama diserta acerca de la gravitación por la imagen, y en este sentido relaciona el diario del magnífico poeta cubano José Martí con "la casa de los duques" del Quijote. El espacio ha sido hechizado, incluso antes de la llegada del hidalgo caballero y se compara al espacio al que llega Martí, que se puebla de recuerdos y ecos del pasado. Los espacios que Martí describe están llenos de poesía, cargados de significación, de cubanía, que decía Lezama. El texto de Martí reproducido fielmente por Lezama pertenece a su diario del 15 de febrero y describe un viaje de este junto a varios amigos a Santiago de los Caballeros ${ }^{27}$. Esta misma idea es repetida por Lezama cuando dice que "En América la novela comienza en lo maravilloso, lo sorprendente. A mi manera de ver ese hombre americano crea lo que yo llamo una cantidad hechizada, como se ve en el Diario de Martí y en la segunda parte del Quijote."28. Lezama encarna en el poeta José Martí la era imaginaria que él llama "la posibilidad infinita", la de la imagen, la de la palabra modelada como nadie por Martí, pero también por Cervantes, comparados en este texto ensayístico. Otro comentario de similar significado aparece recogido en "Introducción a la Esferaimagen", texto publicado en La Prensa Literaria, Managua, el 14 de agosto de 1976, p. 9, que dice: "Lo que más admiro es lo que he llamado la cantidad hechizada en la que se logra la sobrenaturaleza, por ejemplo, la visita de Don Quijote a la casa de los Duques." 29 , entendiendo por sobrenaturaleza, la nueva cara del mito, que se alcanza a través de la imagen.

También son interesantes otro tipo de apuntes y comentarios de Lezama acerca de Cervantes y del Quijote como cultura, literatura o como lecturas que revelan la gran importancia de nuestro autor y su insigne obra para el escritor cubano.

En primer lugar destaca como buen lector del Quijote, asunto desvelado en varios documentos. En su "Cuaderno de apuntes", publicado junto a otros textos en el volumen titulado La posibilidad infinita. Archivo de José Lezama Lima (Madrid: Verbum, 2000), anota, entre otras cosas, los libros que ha prestado y a quien. En concreto a Eloísa Casalduero le dejó "J. Casalduero - Cervantes" (p. 123) que podría tratarse de alguno de los libros escritos por este acerca de Cervantes como su Sentido y forma de las Novelas Ejemplares o Sentido y forma del teatro de Cervantes, publicados en 1969 y 1974, respectivamente.

Y en otra página escribe:

27. José MARTí, Obra literaria, prólogo, notas y cronología de Cintio Vitier, Caracas: Ayacucho, 1989, p. 353.

28. p. 583, citado por José Prats Sariol, "Paradiso: recepciones", en José Lezama Lima, Paradiso, ed. crítica de Cintio Vitier (coord.), Nanterre: Archivos, 1988, pp. 565-589.

29. La posibilidad infinita. Archivo de José Lezama Lima, Madrid: Verbum, 2000, p. 288. 
$308 \cdot$ MACARENA CUIÑAS GÓMEZ

"Yo quienquiera que fuere
Avellaneda - Quijote apócrifo
Yo sé quien soy.
Don Quijote -
Notas para un sistema poético del mundo." (p. 154)

La afirmación quijotesca pertenece al capítulo 5 de la primera parte. Anotación que denota la afirmación de la identidad del hidalgo manchego "verdadero" frente a la imitación que no se reconoce en nadie, además de la aplicación que estas palabras cervantinas tienen en el universo poético y mental lezamiano.

Pero también leemos otros comentarios que revelan un estudio de la crítica sobre nuestros clásicos áureos. Por ejemplo, en Diarios [1939-49 / 1956-58] (México: Era, 1994) encontramos en diciembre 10-43: "Vossler dice que Don Quijote, La Dorotea, son consecuencias de literaturizar la vida o de vivir la literatura." (p. 72). Lezama opinaba que vida y cultura son una misma cosa y no hay porqué separarlas ni hablar de primacías. En este comentario pone un ejemplo de Lope de Vega, La Dorotea, en el que se ha dicho que Lope noveló sus amores con Elena Osorio, amores de juventud retratados desde la madurez vital. En este sentido las referencias al Quijote no serían equiparables, puesto que en el caso de este, es el personaje el que vive como los caballeros andantes de la ficción literaria y confunde su realidad con la fantasía. Cervantes no convierte su vida en literatura como hizo Lope tantas veces. Es su personaje el que vive con pasión un papel ficticio.

Y en el artículo dedicado a lo que Lezama llamaba el Curso Délfico, incluido en estos Diarios, cita (p. 115) a Cervantes como uno de los grandes escritores españoles de todos los tiempos, lectura obligada para toda persona que desee alcanzar la cultura. Lezama, como promotor de la misma, ideó el curso délfico después de años de orientar la lectura de muchos jóvenes que se lo solicitaban. Huelga decir que su biblioteca era amplísima en temas y volúmenes, por lo que creó este curso que dividió en tres etapas: la obertura palatal, la de la gustación de la buena literatura, etapa que no se cierra nunca; la galería délfica o curso délfico propiamente dicho, que es el estudio de la historia de la cultura; y la etapa de las aporías eleáticas, la de los juegos de la cultura y la inteligencia (p. 114). Como ya expresó en otro lugar, para él Cervantes junto con Herrera, constructor del monasterio de El Escorial, era el clásico español por excelencia (pp. 55-56).

Por supuesto, para alcanzar la opinión anterior era necesario un amplio conocimiento y una, digamos, profunda devoción hacia Cervantes. Un amigo de Lezama, Manuel Pereira, narró en su artículo "El curso délfico" 30 conversaciones y momentos vividos con el poeta cubano a lo largo de

30. En Paradiso, edición crítica de Cintio Vitier, Nanterre: Archivos, 1988, pp. 598-618.

ANALES CERVANTINOS, VOL. XXXVII, PP. 297-311, 2005. ISSN: 0569-9878 
su participación en dicho curso, en el que se trasluce la amistad y respeto que surgió entre ambos. Decía:

"[...] pronto adquirimos la costumbre de intercambiar citas. No era un alarde de pedantería, sino que también ese recurso lúdico, sin que yo lo sospechara, formaba parte de mi formación literaria. Si él me decía "¿metafísico estáis?" yo debía responder, remedando un pasaje del Quijote: "Es que no como."." (p. 611)

Además, dice "También citaba mucho esta angustia de Cervantes: "de todas partes me llegan avisos de que me apresure"”' (p. 611). Y acerca de su dedicación a la poesía le decía:

"No haga como los poetastros, que están siempre pendientes del último premio y sólo escriben pensando en el próximo concurso. Ni Cervantes, ni Flaubert, ni Goethe ni Martí enviaron sus páginas a ningún concurso.” (p. 611).

Y en una entrevista de Salvador Bueno titulada "Un cuestionario para José Lezama Lima"31 a la pregunta catorce "¿Qué libros influyeron más en usted y decidieron el camino de su obra?" contesta:

"Mi Eros de conocimiento se volcaba en una incesante lectura. La frase bíblica cómete este libro, tenía en mí una realidad. Leer era para mí una nutrición orgánica. Conviene recordar que El libro de la vida hace fulgurar todo nominalismo que allí se inscribe. Sin embargo, los frutos del árbol del conocimiento descaecen, se pierden, gimen. Un libro puede ser una Vida, ese es el único conocimiento, el otro es el fragante que le corresponde a la muerte con su interrogante grandeza. Los libros o las palabras que más he repasado son los de los fundadores de religiones, Laotsé, Buda, el doctor Kung-Fu, la Biblia. La dialéctica griega y la Ananké, Platón y los trágicos griegos, Santo Tomás de Aquino y el Dante, Vico, Cervantes, Góngora, Quevedo, Goethe, Mallarmé, Claudel, Valèry, Proust y Martí. Lo entrevisto, lo entreoído, lo extrasensorial, el relámpago.” (pp. 728-729).

Desde sus conocimientos de filosofía, sus grandes lecturas de literatura y ensayo, Lezama reclama para la crítica literaria una mayor amplitud de miras, una visión más poética del texto y más flexible en lo que se refiere a la influencia entre escritores, sobre todo la que se establece entre la cultura americana y la española, receptora de una enorme riqueza de imágenes, como

31. También reproducida en la edición de Cintio Vitier de Paradiso, Nanterre: Archivos, 1988, pp. $725-730$ 
expresa Lezama a través de sus eras imaginarias llamadas "las piedras incaicas" y "la posibilidad infinita". De ahí la inquina que muestra por Menéndez Pelayo y por la estilística. Destaca, por el contrario, el talento libre de Cervantes por encima de cuestiones a las que se refiere el cervantismo, como por ejemplo, que el inicio del Quijote se haya producido en una prisión o que este se haya escrito contra los libros de caballerías. Cervantes era un hombre avanzado para su tiempo, abierto a otras culturas, por eso su literatura no muere porque está revisitada por el tiempo, cada lector de cada época y cultura convierten en universal su significado. Cervantes, como José Martí, es un escritor que llega más allá, crea nuevos mundos y significados generando imágenes a través de palabras.

Sin duda el español constituía para José Lezama Lima el gran escritor a través de cuyas palabras se podía apresar la imagen, la metáfora, la sensación, el sentimiento, entrever el pensamiento plasmado por Cervantes en el Quijote al igual que Lezama construye en Paradiso su ingente sistema poético del mundo.

Lezama sentía devoción por Cervantes y su obra, era para él lectura clave, como se reproduce más arriba, "lo entrevisto, lo entreoído, lo extrasensorial, el relámpago". Esto es Cervantes para Lezama: la genialidad poética, que muchas veces no se muestra claramente al lector pero que subyace como un latido.

\section{BIBLIOGRAFÍA}

Batalllon, Marcel, "Relaciones literarias", Suma cervantina, editada por J. B. AvalleArce y E. C. Riley, London: Tamesis Books Limited, 1973, pp. 215-232.

CASTro, Américo, Cervantes y los casticismos españoles, Madrid: Alianza, Alfaguara, 1974.

Cervantes Saavedra, Miguel de, Don Quijote de la Mancha, edición del Instituto Cervantes dirigida por Francisco Rico, Barcelona: Crítica, 1998.

- Obras completas, edición de Florencio Sevilla, Madrid: Castalia, 1999.

- Ocho novelas ejemplares, edición de José Montero Reguera, Barcelona: De Bolsillo, 2002.

CRos, Edmond, Mateo Alemán: Introducción a su vida y su obra, Salamanca: Anaya, 1971.

Ferrater Mora, José, Diccionario de filosofía, Buenos Aires: Edición Sudamericana, 1971.

LeZama Lima, José, Paradiso, edición crítica de Cintio Vitier, coordinador, Nanterre: Asociación ALLCA XXe, Colección Archivos, 1988.

- El reino de la imagen, selección, prólogo y cronología de Julio Ortega, Caracas: Biblioteca Ayacucho, 1981.

- Diarios [1939-49/1956-58], compilación y notas de Ciro Bianchi Ross, México: Ediciones Era, 1994.

- La posibilidad infinita. Archivo de José Lezama Lima, introducción, transcripción, selección y notas Iván González Cruz, Madrid: Verbum, 2000.

LÓPEZ NAviA, Santiago A., Inspiración y pretexto. Estudios sobre las recreaciones del Quijote, Madrid: Vervuert, 2005. 
Márquez Villanueva, Francisco, Trabajos y días cervantinos, Alcalá de Henares: Centro de Estudios cervantinos, 1995.

MARTí, José, Obra literaria, prólogo, notas y cronología de Cintio Vitier, Caracas: Biblioteca Ayacucho, 1989.

MenÉndez Pelayo, Marcelino, "Cultura literaria de Miguel de Cervantes", en Cervantes. Cultura literaria. 450 Aniversario del nacimiento de Cervantes, Alcalá de Henares: Centro de Estudios cervantinos, 1997, pp. 7-25.

Montero Reguera, José, El Quijote y la crítica contemporánea, Alcalá de Henares, Centro de Estudios Cervantinos, 1997.

Orozco, Emilio, Introducción a Góngora, Barcelona: Crítica, 1984.

PIEPER, Josef, Filosofía medieval y mundo moderno, Madrid: ediciones Rialp, 1973.

PorTolés, José, Medio siglo de Filología española (1896-1952). Positivismo e idealismo, Madrid: Cátedra, 1986.

RiQuer, Martín de, "Cervantes y la caballeresca", Suma cervantina, editada por J. B. Avalle-Arce y E. C. Riley, London: Tamesis Books Limited, 1973, pp. 273-292.

SÁEnz de Santa María, Carmelo, Garcilaso de la Vega el Inca, Madrid: Historia 16, 1987

VoSSLER, Karl, Lope de Vega y su tiempo, Madrid: Revista de Occidente, 1933.

- Introducción a la literatura española del siglo de oro, Madrid: Visor libros, 2000 (1 ${ }^{\mathrm{a}}$ ed. Cruz y Raya, 1934).

\section{Resumen}

El presente artículo pretende adentrarse en la relación que el escritor cubano José Lezama Lima entabló con la personalidad y la obra de Miguel de Cervantes como lector, crítico y poeta. En concreto se centra en las reflexiones desarrolladas por Lezama acerca del Quijote, de Cervantes y el cervantismo, en su obra de ficción y ensayística.

Palabras clave: Cervantes, Quijote, Lezama, poesía, ensayo, filosofía, crítica.

\section{Summary}

This article tries to analize the influence of Cervantes, his personality and literary production, in the cuban writer José Lezama Lima as a reader, critic and poet. This study explains Lezama's thoughts about Quijote, Cervantes and the cervantism in his fiction and essay work.

Key words: Cervantes, Quijote, Lezama, poetry, essay, philosophy, criticism. 